\title{
Remanent magnetization of oolitic ironstone beds, Hazara area, Lesser Himalayan thrust zone, Northern Pakistan: Its acquisition, timing, and paleoenvironmental implications
}

\author{
Mitsuo Yoshida*, Ibrar H. Khan, and Mirza Naseer Ahmad \\ Geoscience Laboratory, Geological Survey of Pakistan, Shahzad Town, P.O. Box 1461, Islamabad, Pakistan
}

(Received January 27, 1997; Revised May 15, 1998; Accepted May 19, 1998)

\begin{abstract}
Chamosite-hematite type oolitic ironstone is distributed in the Cretaceous-Tertiary (K-T) boundary zone of the Hazara area, Lesser Himalayan thrust zone, in the northwestern margin of the Indo-Pakistani subcontinent. A total of 52 oriented samples were collected from 6 beds in two open pit mines, Nathia Gali and Bagnotar. Ferromagnetic properties of the oolitic ironstone are dominated by fine-grained hematite that possesses a characteristic remanent magnetization (ChRM). The ChRM is a chemical remanent magnetization (CRM) acquired by the hematite which formed from Fe-rich initial materials (iron hydroxides) during early diagenesis of the ironstone bed. The direction of the remanent magnetization indicates that the magnetization was acquired in an equatorial region (average inclination $=2^{\circ}$, paleolatitude $=1^{\circ} \mathrm{N}$ ), which is consistent with the paleoposition of the Indian subcontinent during early Paleocene time, as estimated by previous data. The initial Fe-rich sediments were deposited under anoxic conditions, probably in a non-marine or brackish environment. During early diagenesis, after development of oolitic textures, the paleoenvironment became arid, where the CRM was acquired through the conversion of amorphous hydroxides or goethite to fine-grained hematite. The paleomagnetic results reveal complicated local rotational movements of oolitic ironstone blocks about vertical axes, which might be a result of intense thrusting within the terrane after early Tertiary collision between India and Asia.
\end{abstract}

\section{Introduction}

Phanerozoic sedimentary ironstones are usually thin sequences with oolitic textures which were deposited in shallow-marine or non-marine environments (Young and Taylor, 1989; Taylor, 1992). The oolitic texture (or oolite) in sedimentary ironstones consists of concentric rings of $\mathrm{Fe}$ bearing minerals generally from the hematite $\left(\mathrm{Fe}^{3+}{ }_{2} \mathrm{O}_{3}\right)$ chamosite $\left((\mathrm{Mg}, \mathrm{Fe})_{3} \mathrm{Fe}_{3}\left(\mathrm{Si}_{3} \mathrm{Al}\right) \mathrm{O}_{10}(\mathrm{OH})_{8}\right)$ assemblage or the goethite $\left(\mathrm{Fe}^{3+} \mathrm{OOH}\right)$-berthierine $\left(\left(\mathrm{Fe}_{4}{ }^{2+} \mathrm{Al}_{2}\right)\left(\mathrm{Si}_{2} \mathrm{Al}_{2}\right)\right.$ $\left.\mathrm{O}_{10}(\mathrm{OH})_{8}\right)$ assemblage (Tucker, 1991). It has been widely believed that the concentric rings of oolite were initially formed by a chemical precipitation process.

The occurrence of oolitic ironstones generally corresponds to times of high relative sea-level, when climate was generally considered to have been warm and humid, which facilitated chemical weathering (Blatt et al., 1980; Gilbert and Park, 1986). These observations suggest that oolitic ironstones, especially hematite-bearing types, may be able to maintain a chemical remanent magnetization (CRM) which may be useful for paleomagnetic studies. However, the process by which oolitic textures form and the timing of crystallization of hematite in these rocks is still a matter of debate (Maynard, 1983; Young and Taylor, 1989; Kimberley, 1994).

*Present address: Geoscience Analysis Center, Geoscience Co., Ltd. 13-14, Moto Asakusa 3, Taito, Tokyo, Japan.

Copy right $(\subset)$ The Society of Geomagnetism and Earth, Planetary and Space Sciences (SGEPSS); The Seismological Society of Japan; The Volcanological Society of Japan; The Geodetic Society of Japan; The Japanese Society for Planetary Sciences.
Oolitic ironstones are widely distributed in Mesozoic to early Tertiary formations in the northwestern Lesser Himalayas, Pakistan (Ahmad, 1969; Maynard, 1983; Hallam and Maynard, 1987; Garzanti, 1993). In this study, we describe results of mineralogical, rock-magnetic, and paleomagnetic analyses of one of the major oolitic ironstones exposed in Hazara area in the Lesser Himalaya of Northern Pakistan. The paleoenvironment of the oolitic ironstone formation, in the light of our results, is also discussed.

\section{Geologic Setting and Sampling}

The Hazara area lies in the crescent-shaped NE-SW trending Lesser Himalayan terrane which forms the western limb of the Hazara-Kashmir Syntaxis, at the northwestern margin of the Indo-Pakistani subcontinent (Fig. 1). The Hazara area (or "Hazara Arc", cf. Butt, 1989) is bounded by two major thrust faults, the Panjal Thrust and the Main Boundary Thrust (MBT), and a number of local thrust fault that lie in a similar NE-SW trend (Fig. 2).

We studied oolitic ironstone beds which are referred to as the Langrial iron ore deposits (Khan and Ahmad, 1966) which are currently being exploited by local small-scale open pit mines. The ironstone beds are overlain by limestone beds of the Lockhart Formation and are underlain by limestone beds of the Kawagarh Formation. The Lockhart Formation contains abundant foraminifera which indicate a Paleocene age, while the Kawagarh Formation has been dated as Late Coniacian to Campanian (Late Cretaceous), based on limited paleontological data (Fatmi, 1974; Ibrahim Shah, 1977). The oolitic ironstone beds are residual deposits 


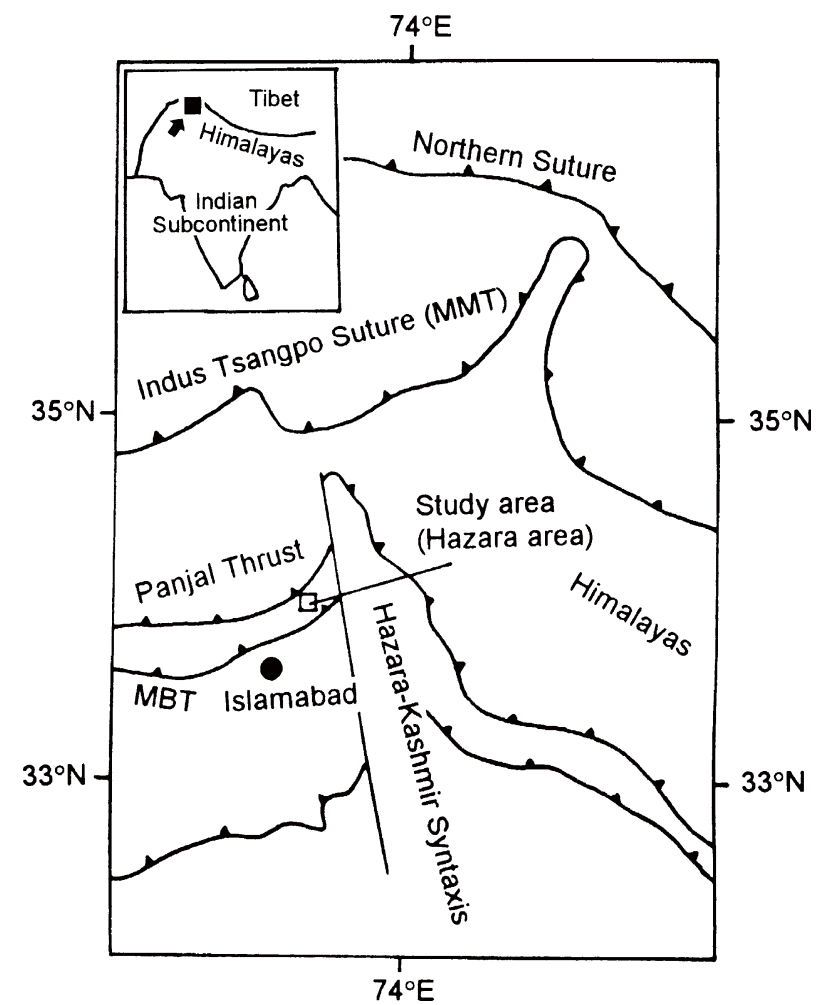

Fig. 1. Tectonic sketch map of Northern Pakistan (modified from Kazmi and Rana, 1982), and the study area.

which mark a significant time gap across the CretaceousTertiary (K-T) boundary. The ironstone beds generally consist of 2 to $5 \mathrm{~cm}$ layers of dark brown lenticular ferrous materials within poorly sorted massive brown sandy siltstone.

The oolitic ironstone beds have a maximum thickness of $3 \mathrm{~m}$ in the area and are highly deformed and sheared by a number of NE-SW trending thrust faults which form an imbricated thrust structure (Fig. 2). The beds form a SEdipping monoclinal structure in the Bagnotar and Nathia Gali open pit areas. A total of 52 oriented samples were collected from the ferrugenous layers that are exposed at two sites (beds) at the Nathia Gali open pit and at four sites (beds) at the Bagnotar open pit in the eastern part of the Hazara area (Fig. 2).

\section{Petrography and Mineralogy}

The ironstone appears as fragile dark brown sandy siltstone, with oolitic texture in hand samples. To determine the mineralogical composition and petrologic nature of the ironstone, petrographic observation, X-ray diffraction (XRD) analysis, and electron probe micro analysis (EPMA) were applied to selected samples.

\subsection{Petrographic observation}

Petrographic observations using a polarized optical microscope indicate that the ironstone comprises ooids and subangular to subrounded quartz grains $(0.4 \sim 0.02 \mathrm{~mm}$ diameter, average $0.1 \mathrm{~mm}$ diameter) in a calcareous cement (Plate 1). The matrix color is due to the presence of hematite pigment and goethite. The ooids are generally larger than the quartz grains and are highly variable in shape, varying from spherical to irregular ellipsoidal. Although most of the

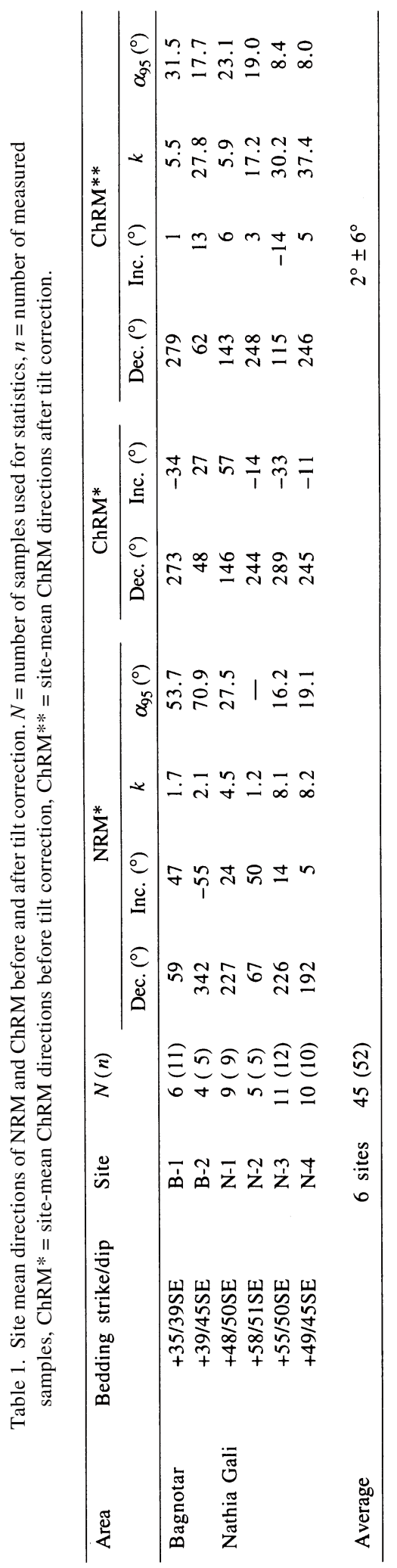




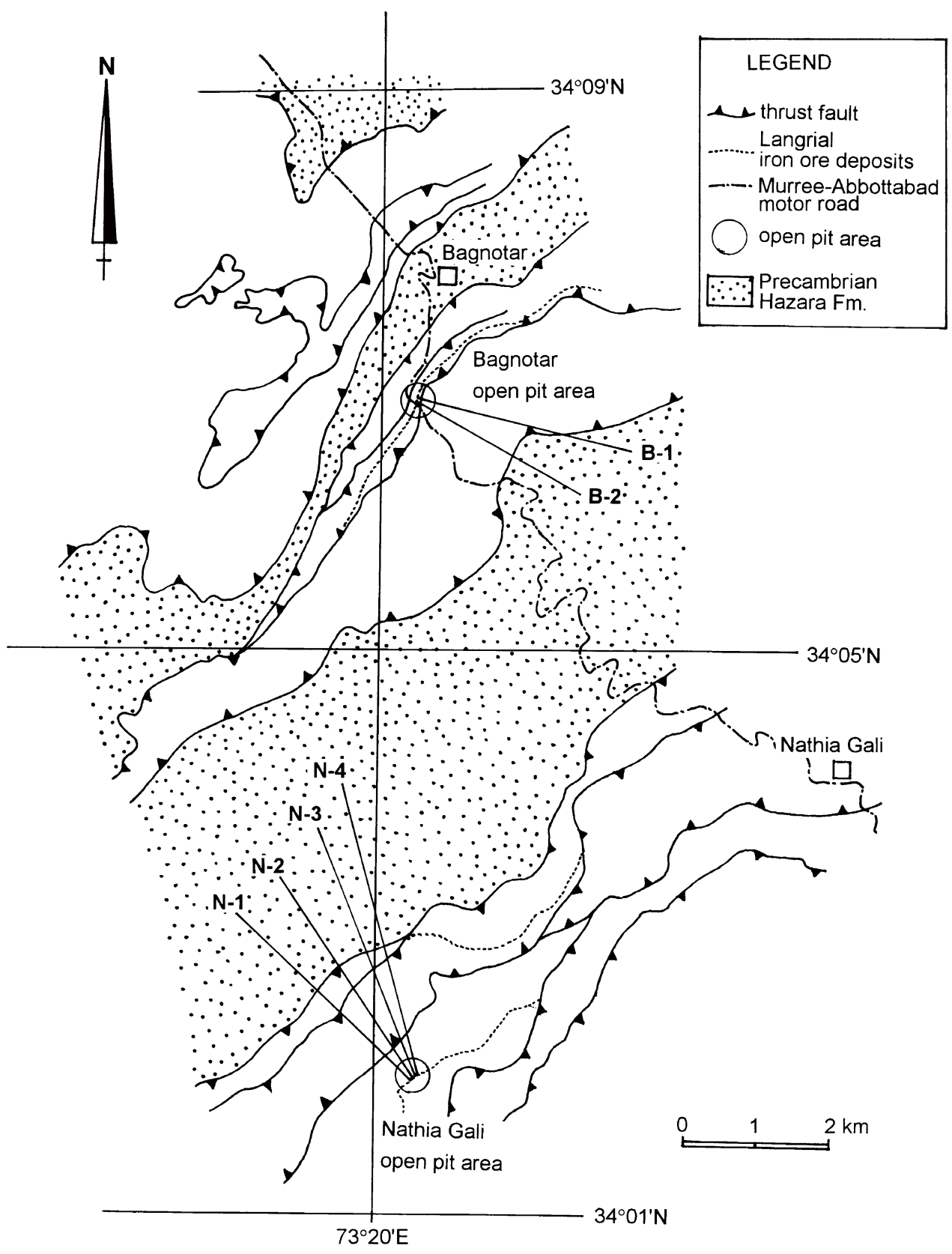

Fig. 2. Location of sampling sites of the Langrial iron ore deposits. The distribution of thrust faults is from Khan and Ahmad (1966).

grains are symmetrical, some show distinct asymmetry (Plate 1). The size of the ooids is mostly between $0.8 \mathrm{~mm}$ and $0.2 \mathrm{~mm}$ in diameter, but smaller size ooids $(0.2 \mathrm{~mm}$ to 0.05 $\mathrm{mm}$ in diameter, it is similar size of quartz grains) are also present. The larger ooids sometimes contain several smaller ooids or a fragment of another ooid is present at their center which may have acted as a nucleus. Surrounding laminae have concentric structures, as indicated by dark (opaque) and light bands of minerals at $0.05 \sim 0.01 \mathrm{~mm}$ intervals. Very fine chamosite grains are commonly enclosed in the laminae, and the opaque parts are composed of hematite. Asymmetrical and unbroken ooids are affected by neighboring ooids, which suggests an effect of deformation before complete consolidation but after the formation of the oolitic structure. These features suggest that the ooids formed in situ (or not transported far) and that they initially precipi- tated as gelatinous material which was compacted during early burial, while still soft. The presence of ooid fragments as nuclei of other ooids (see Plate 1) indicates that the formation of ooids occurred repeatedly in a dynamic environment.

The center of the ooids is sometimes replaced by carbonates which cut across the lamellae. Carbonates are also observed in radial fissures in ooids and in veins, which formed after consolidation of the bed.

\subsection{XRD analysis}

XRD analysis was made using a RIGAKU/Geiger Flex ME-20 system, and the interpretation of diffraction charts was conducted using selected JCPDS (ASTM) cards for common minerals. The mineral species identified from the XRD charts include: quartz $\left(\mathrm{SiO}_{2}\right)$, chamosite $\left((\mathrm{Mg}, \mathrm{Fe})_{3} \mathrm{Fe}_{3}\left(\mathrm{Si}_{3} \mathrm{Al}\right) \mathrm{O}_{10}(\mathrm{OH})_{8}\right)$, hematite $\left(\alpha-\mathrm{Fe}_{2} \mathrm{O}_{3}\right)$, with a 


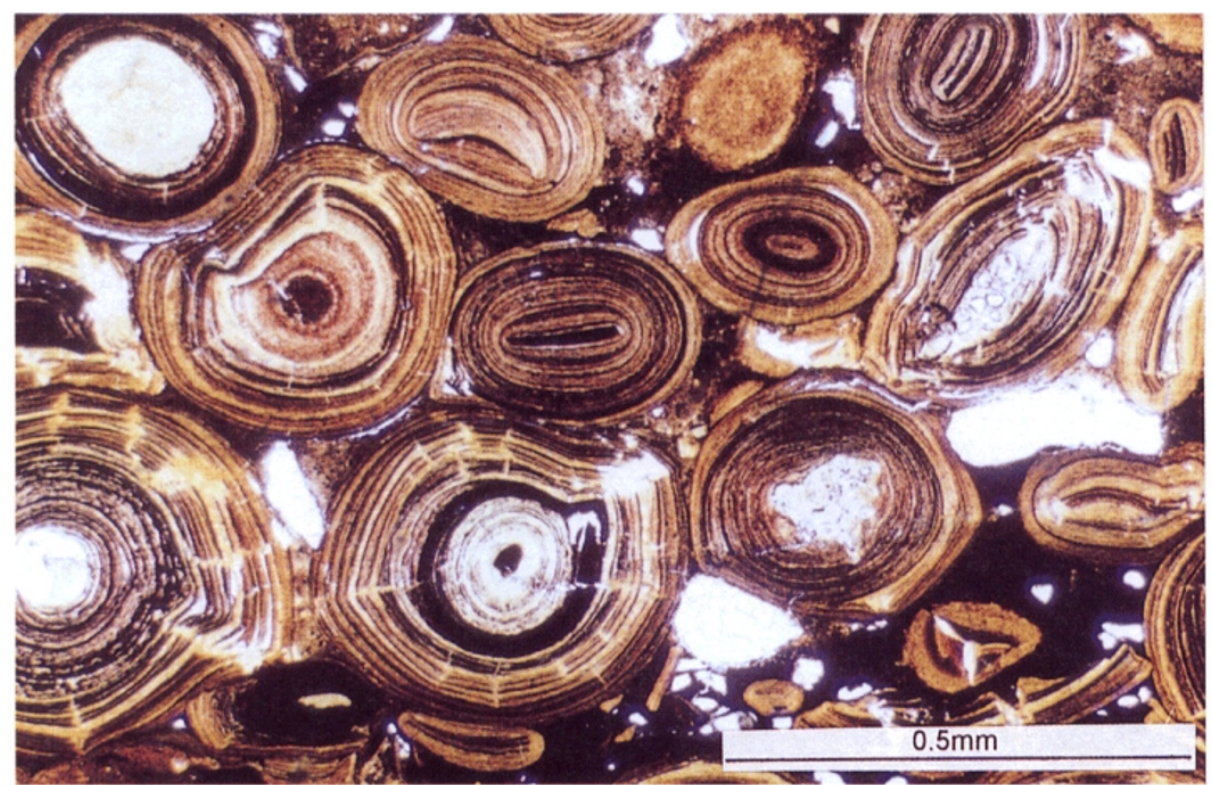

Plate 1. Photomicrographs of oolitic ironstone (sample B-1-1 from Bagnotar open pit) under transmitted polarized light (parallel nicols). Light-colored rings are mainly composed of chamosite and the dark (opaque) parts are composed of hematite. The symmetrical shape of the ooids is more or less affected by neighboring ooids, which indicates that the deformation occurred before consolidation, but after formation of the oolitic structure. Some ooids contain a fragment of another ooid (at their center) which may have acted as a nucleus.

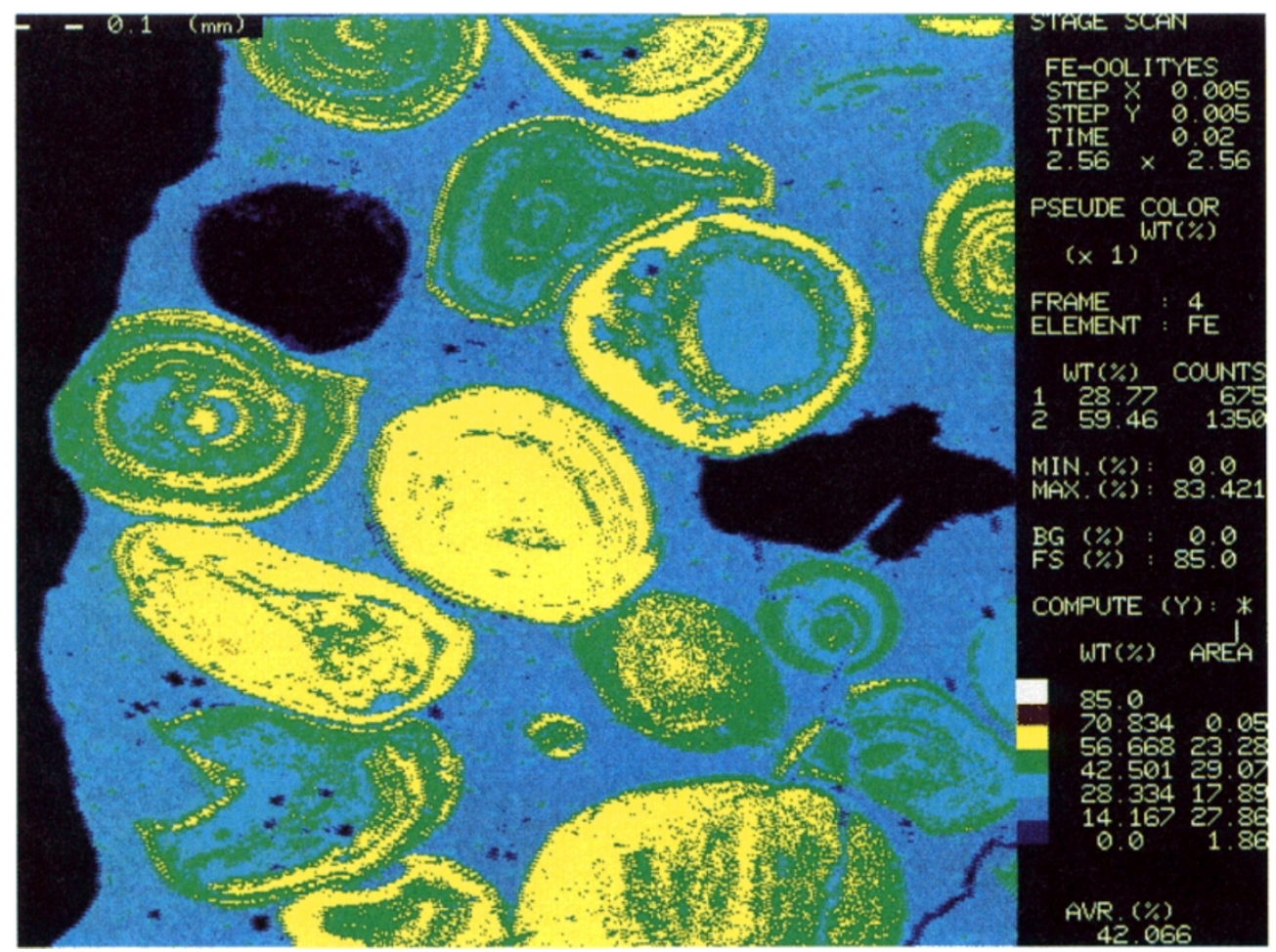

(a)

Plate 2. Compositional maps of the distribution of (a) $\mathrm{Fe}$, (b) Si, and (c) Al in terms of the relative X-ray intensities of $\mathrm{Fe} \mathrm{K} \alpha$, $\mathrm{Si} \alpha \alpha$, and $\mathrm{Al} \mathrm{K} \alpha$ lines, with intensity ranges of each element displayed as pseudocolors in the form similar color pallette for each map. Brightness is an indication of elemental abundance.

minor amount of goethite $(\alpha$-FeOOH $)$, smectite $\left((\mathrm{Ca}, \mathrm{Na})_{0.7}(\mathrm{Al}, \mathrm{Mg}, \mathrm{Fe})_{4}(\mathrm{SiAl})_{8} \mathrm{O}_{20}(\mathrm{OH})_{4} \mathrm{H}_{2}\right)$, and siderite $\left(\mathrm{FeCO}_{3}\right)$. The presence of berthierine $\left(\left(\mathrm{Fe}_{4} \mathrm{Al}_{2}\right)\left(\mathrm{Si}_{2} \mathrm{Al}_{2}\right)\right.$ $\mathrm{O}_{10}(\mathrm{OH})_{8}$ ) was looked for but it was not detected (Fig. 3).

\subsection{EPMA analysis}

Because the ooids have layers with different compositions which vary in mineralogy, a compositional mapping by EPMA for 6 elements (Fe, $\mathrm{Ti}, \mathrm{Al}, \mathrm{Si}, \mathrm{Mg}$ and $\mathrm{Ca}$ ) was 


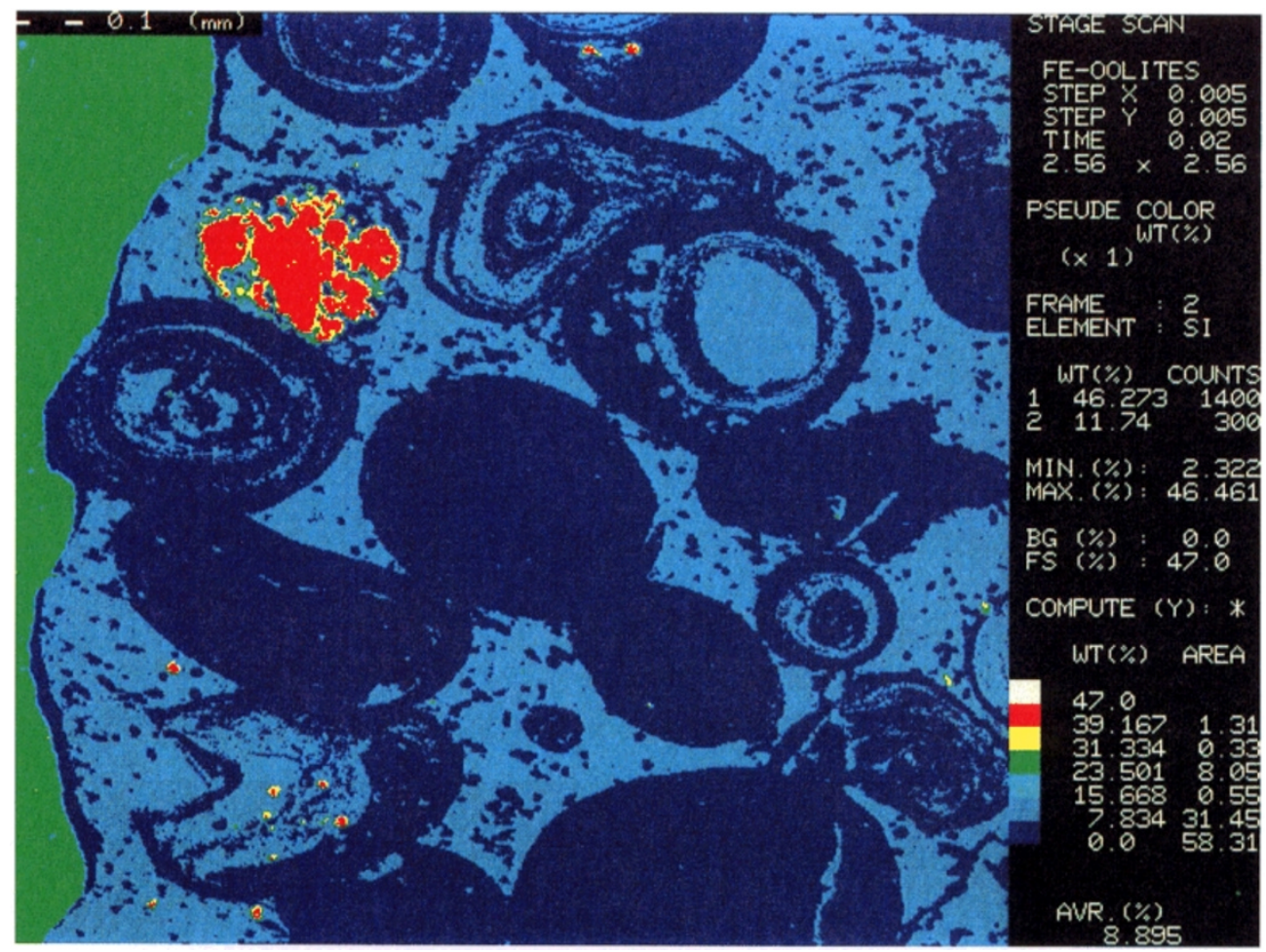

(b)

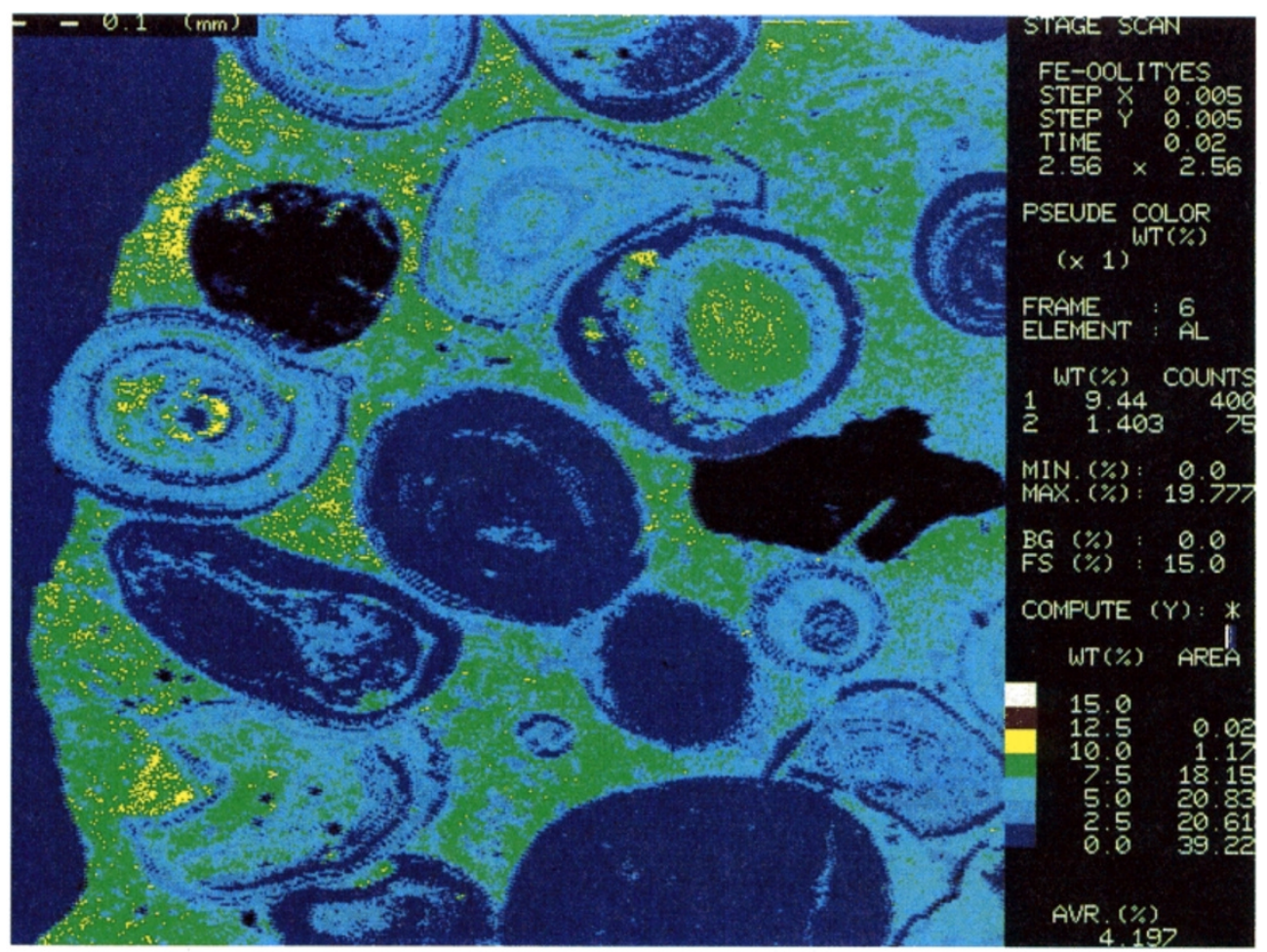

(c)

Plate 2. (continued).

attempted to check their exact distribution. The analyses were performed on gold-coated polished thin sections using a SHIMADU/EPMA-8705 Q-II system.

The results are shown in terms of element concentration for each point which was deduced from the X-ray intensities and quantitative analysis of the X-ray data (Plate 2). Within an ooid, a strong positive correlation exists between $\mathrm{Al}, \mathrm{Mg}$, and $\mathrm{Si}$, whereas a clear negative correlation exists between 


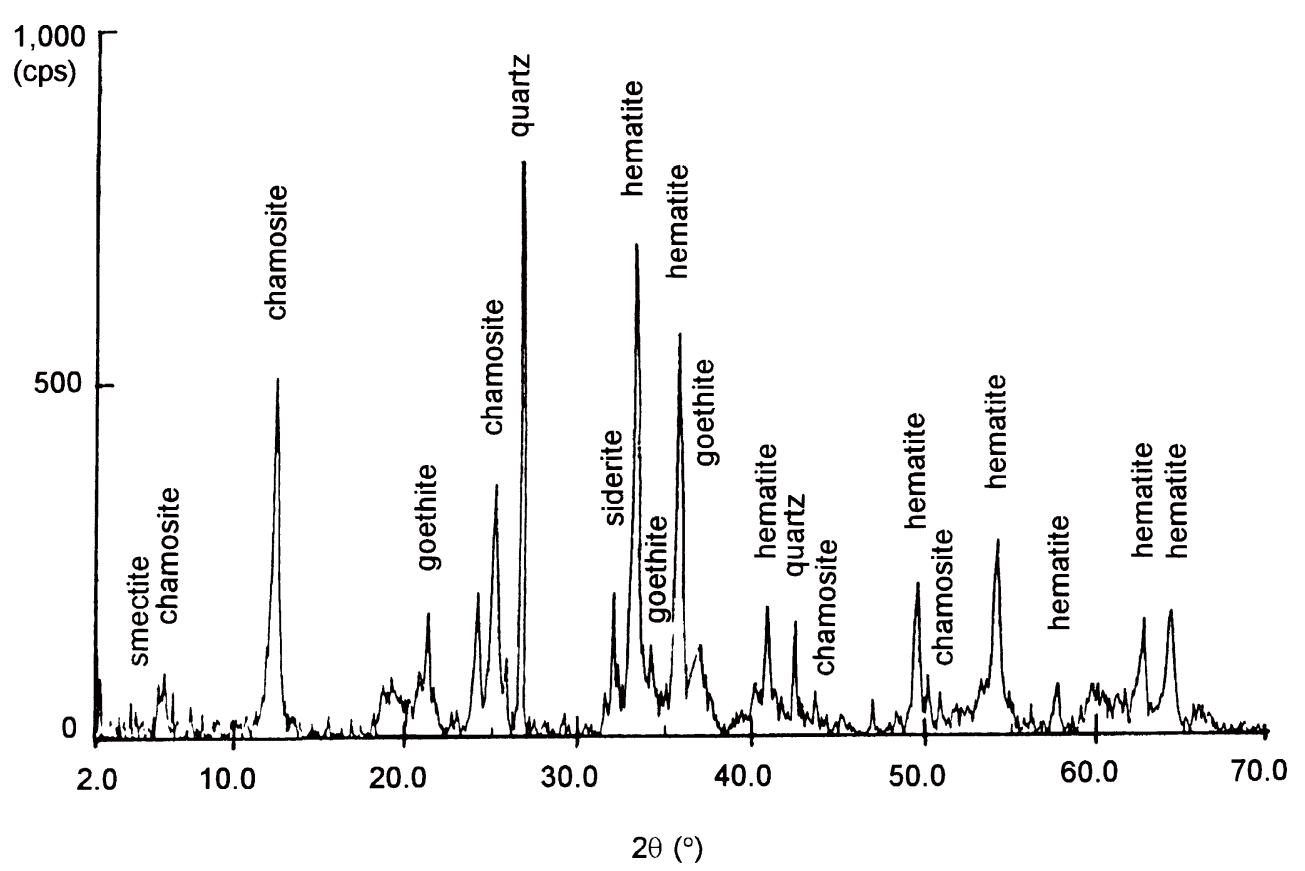

Fig. 3. X-ray diffraction (XRD) pattern by $\mathrm{CuK} \alpha$ of powdered bulk specimen of oolitic ironstone.

these elements and Fe. The ooid rings which indicate higher concentrations of $\mathrm{Al}, \mathrm{Mg}$, and $\mathrm{Si}$, represent the distribution of chamosite, while those with higher Fe concentration represent hematite concentrations.

\section{Rock Magnetism}

Thermomagnetic analysis, and IRM acquisition experiments were carried out to determine the magnetic properties of the oolitic ironstone. Thermomagnetic properties were measured with a horizontal-translation type automatic magnetic balance, an EIKO/EB-4, at a field of $380 \mathrm{mT}$ between 20 and $740^{\circ} \mathrm{C}$ under vacuum condition $\left(<10^{-3} \mathrm{mmHg}\right)$. From thermomagnetic analysis of a bulk ironstone sample (B-1-a) from the Bagnotar area, three Curie temperatures were recognized (Fig. 4): $\mathrm{Tc}_{1}=120^{\circ} \mathrm{C}$ (very small drop in the heating curve), $\mathrm{Tc}_{2}=560^{\circ} \mathrm{C}$ (observed only in the cooling curve), and $\mathrm{Tc}_{3}=680^{\circ} \mathrm{C}$ (observed in the heating and cooling curves). The Curie temperature $\mathrm{Tc}_{1}$ corresponds to that of goethite and $\mathrm{Tc}_{3}$ corresponds to that of hematite (Carmichael, 1989), which were also identified by optical microscopy and XRD analyses. The Curie temperature $\mathrm{Tc}_{2}$ is consistent with the appearance of a Ti-poor titanomagnetite after heating. The sharp increase in strong-field-induced magnetization ( $\mathrm{Js})$ at room temperature after heating is probably due to production of this Ti-poor titanomagnetite which probably formed by a thermal decomposition of paramagnetic Fe-bearing minerals (chamosite and/or siderite) or by a reduction of hematite under vacuum condition.

The isothermal remanent magnetization (IRM) of bulk samples was measured after placement in a stepwise increasing magnetic field, up to $9.7 \mathrm{~T}$ using a Magnetic Measurement MMPM-9 pulse magnetizer. IRM acquisition curves for magnetite bearing rocks are often characterized by a steep initial increase and by saturation or sharp flattening of the slope at fields of $300 \mathrm{mT}$ or less. On the other hand, those for hematite or goethite bearing rocks are initially convex and reach saturation at very high fields ( 3-5 T) (Lowrie and Heller, 1982). The IRM acquisition curve for the oolitic ironstone sample does not display saturation up to $300 \mathrm{mT}$ and is not saturated until around $5 \mathrm{~T}$ (Fig. 5). This indicates that the sample does not contain magnetite (or Tipoor titanomagnetite) until subjected to high temperatures and that the magnetic carrier in the oolitic ironstones is probably hematite or goethite. The saturation IRM (SIRM) was demagnetized by progressive DC back-field demagnetization (left hand side of Fig. 5). The SIRM has high coercivity and is not reduced to zero until application of a back-field of around $0.7 \mathrm{~T}$, which indicates that the grain size of the hematite/goethite is very fine.

\section{Paleomagnetic Measurement \\ 5.1 Measurement results}

Remanent magnetization was measured using Natsuhara/ SMD-88 and Geofyzika/JR-5A spinner magnetometers. Stepwise thermal demagnetization (THD) in air was conducted with a Natsuhara/DEM-8602 demagnetizer. The NRM intensity of the oolitic ironstone samples varies between $1.2 \times 10^{-1}$ and $2.9 \times 10^{-2} \mathrm{~A} / \mathrm{m}$. The NRM is hardly demagnetized by alternating field demagnetization and only THD is effective. Vector component plots (Zijderveld, 1967) for THD of pilot samples of oolitic ironstones from Bagnotar and Nathia Gali open pits are shown in Fig. 6.

It is obvious that there are at least two different components in the NRM, which can be observed by THD below $500-600^{\circ} \mathrm{C}$ (low temperature component) and above ca. $600^{\circ} \mathrm{C}$ (high temperature component).

The low temperature component maintains most of the NRM intensity (often more than $90 \%$ of total intensity). The vector component plots of the low temperature steps sometimes exhibit such an unstable trajectory that it can be difficult to determine the direction (Fig. 6). Conversely, the 


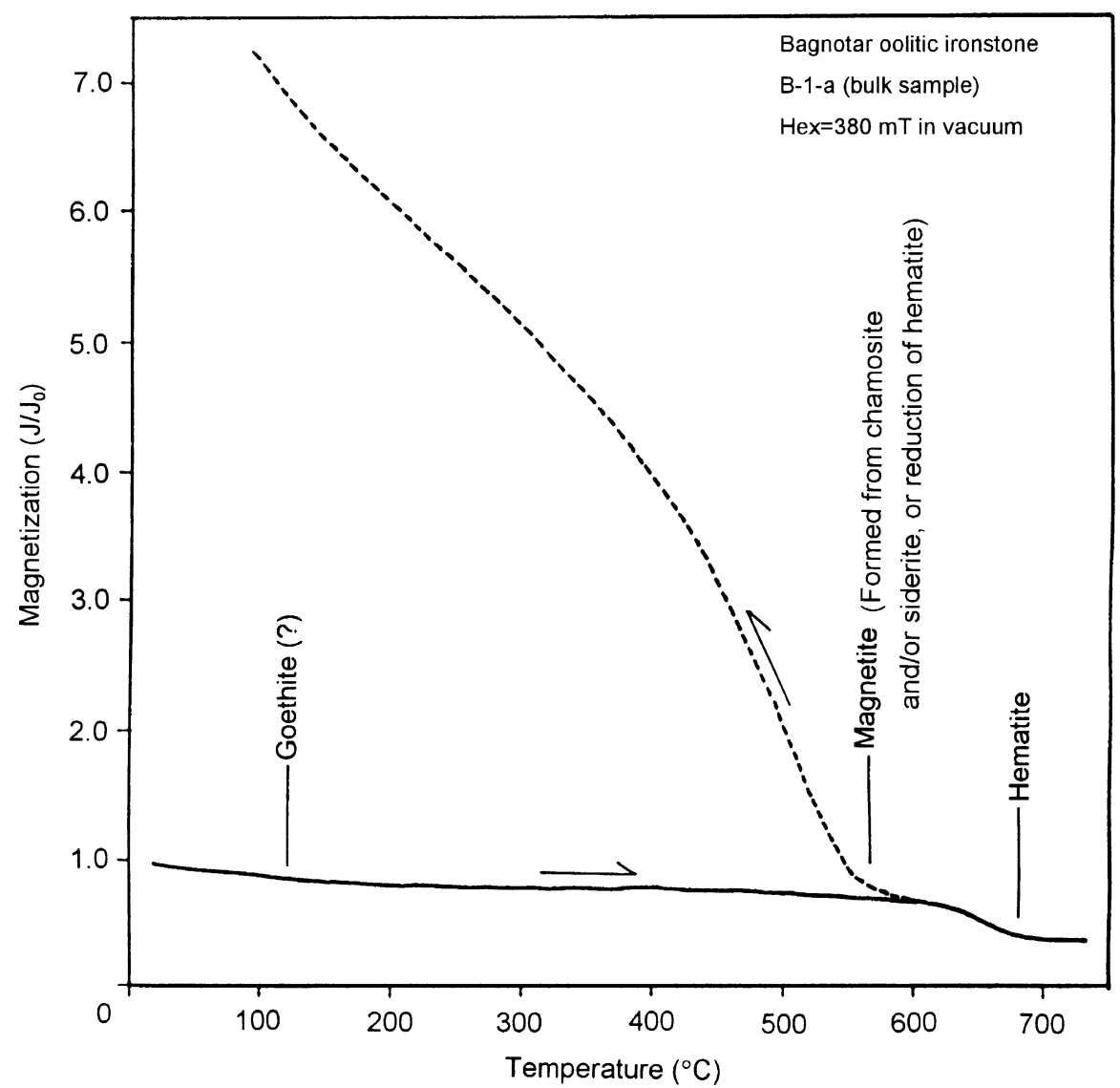

Fig. 4. Thermomagnetic (JS-T) curve of the iron oolite (magnetically non-separated bulk sample). Solid line depicts heating curve and dashed line depicts cooling curve.

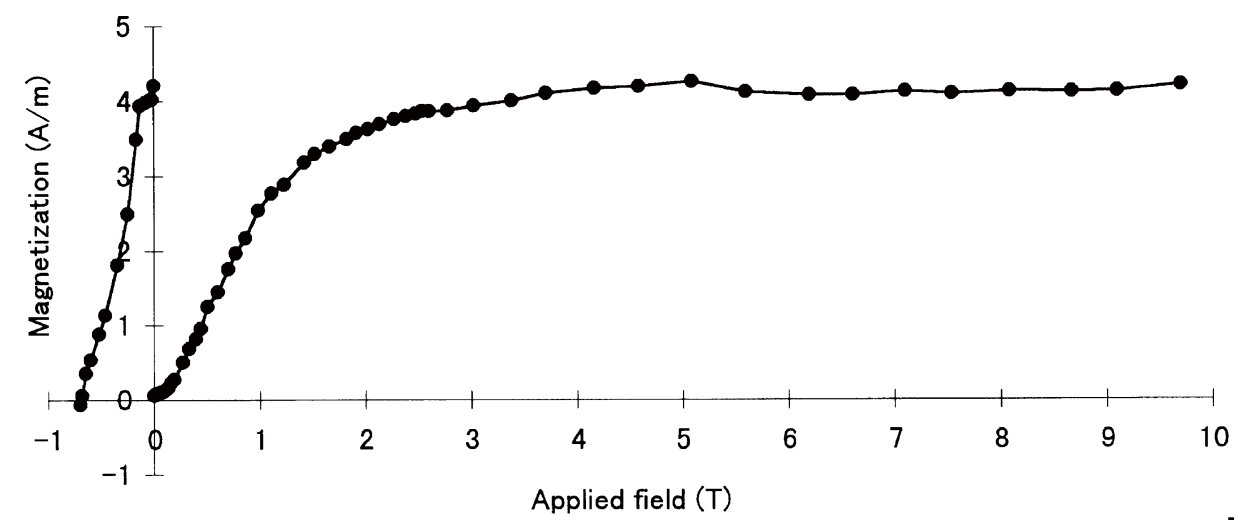

Fig. 5. Isothermal remanent magnetization (IRM) acquisition curve of Hazara iron oolite (right curve). The IRM is not saturated up to $4.2 \mathrm{~T}$. The left hand curve depicts the back-field demagnetization curve after application of an IRM at 4.2 T.

high temperature component, which contributes a smaller part of the NRM intensity (often less than 10\%), is usually represented by a nearly linear segment directed toward the origin of the vector component plot between 600 and $680^{\circ} \mathrm{C}$, which is interpreted to represent the characteristic remanent magnetization (ChRM). We determined the ChRM direction for each sample between 620 and $680^{\circ} \mathrm{C}$. The ChRM directions (high temperature component) are more or less clustered for each site. The measurement results are summarized in Table 1.

\subsection{Site-mean directions}

The distribution of ChRM directions is moderately well clustered at sites B-2, N-2, N-3, and N-4 $\left(\alpha_{95}=8-19^{\circ}, k=\right.$ $17-38)$ but poorly clustered at sites B-1 $\left(\alpha_{95}=32^{\circ}, k=5.5\right)$ and $\mathrm{N}-1\left(\alpha_{95}=23^{\circ}, k=5.9\right)$. It can be recognized that at sites $\mathrm{N}-2$ and $\mathrm{N}-3$, the ChRM directions have an antipodal distribution, and the distribution in the site $\mathrm{N}-3$ passes the reversal test (Class C defined by McFadden and McElhinny, 1990).

The site-mean directions varied site by site in declination, but stayed shallow in all sites (Fig. 7). The discordant 

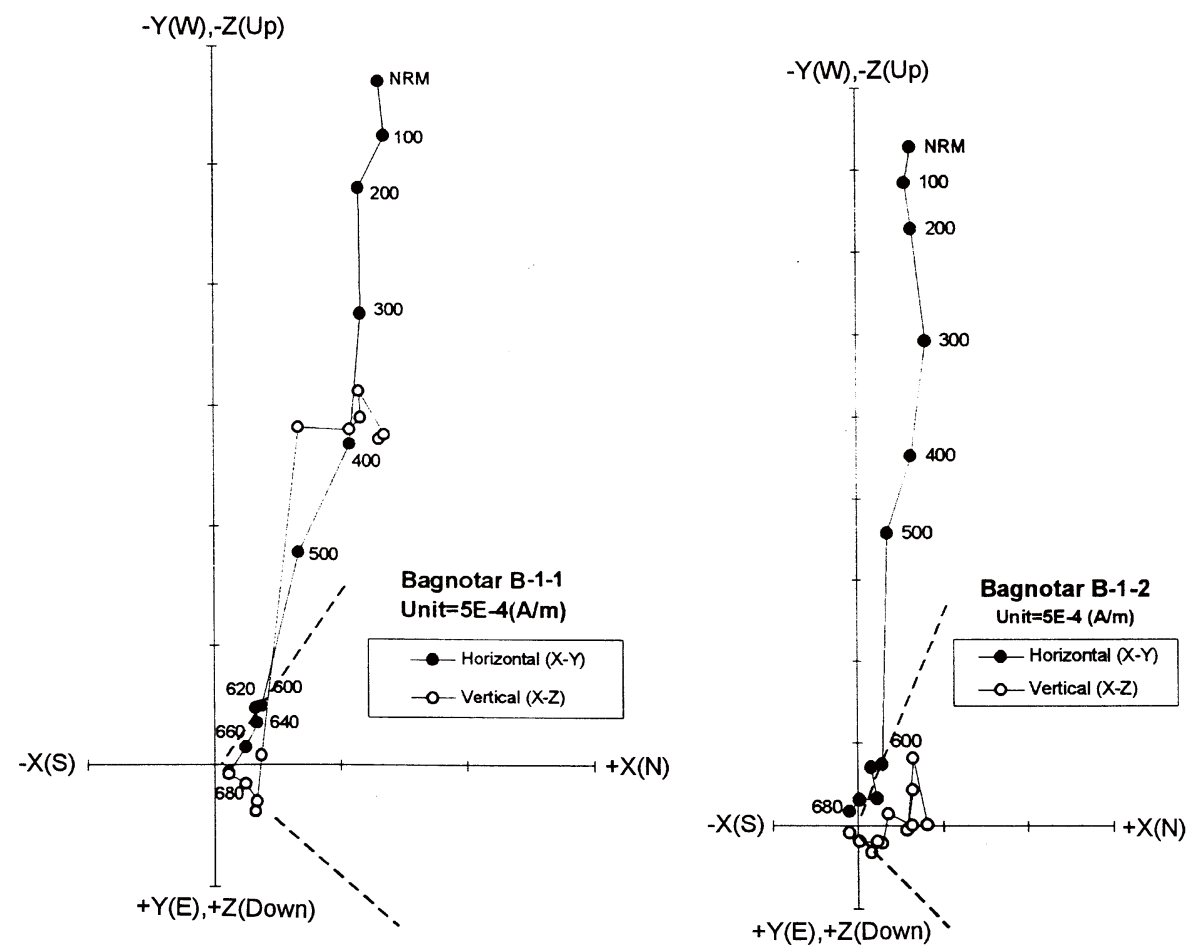

(a)

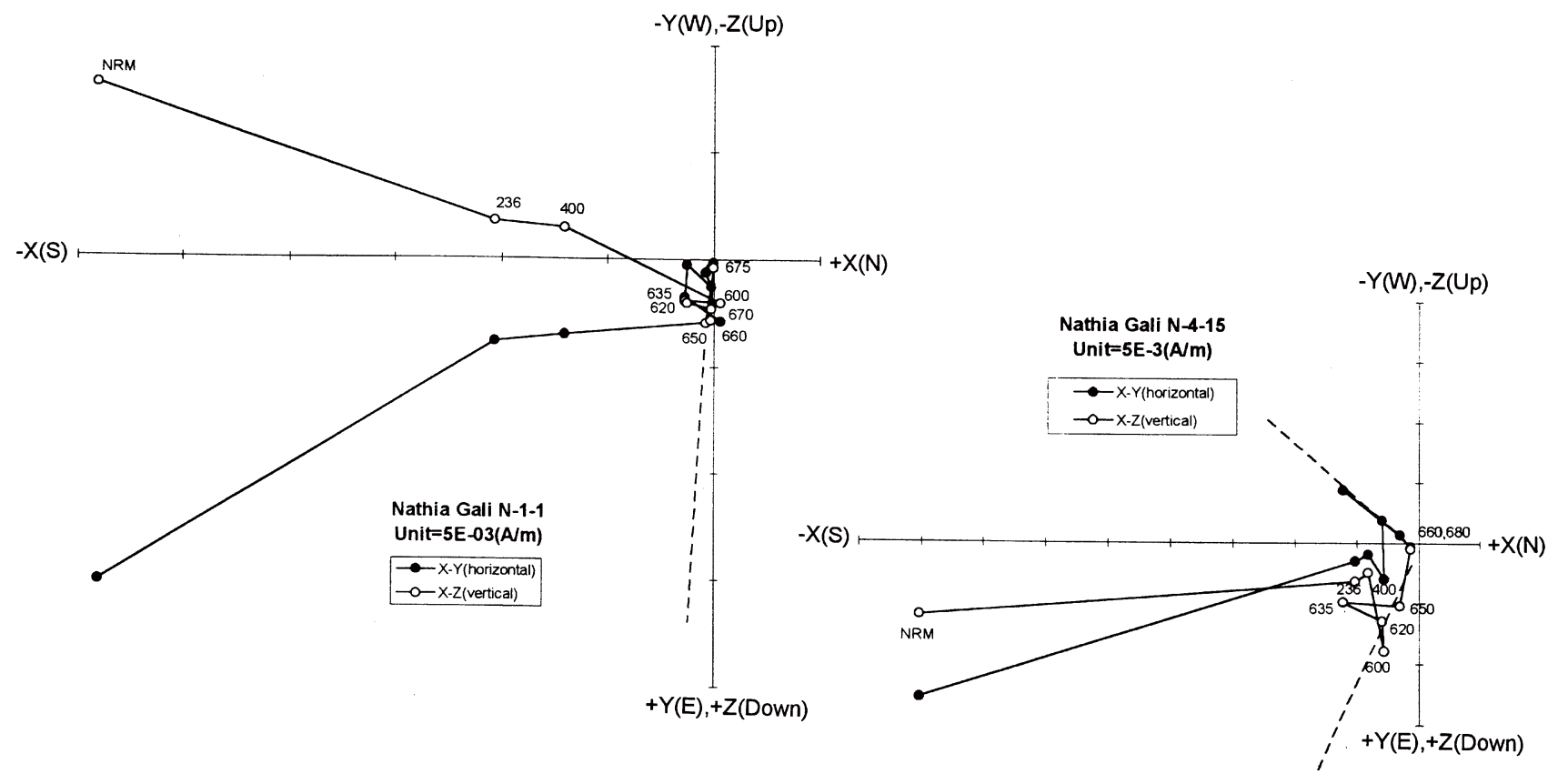

(b)

Fig. 6. Vector component plots of results from progressive thermal demagnetization of oolitic ironstone samples. Numbers indicate THD temperature $\left({ }^{\circ} \mathrm{C}\right)$. Dashed lines give the direction of ChRM component for each sample. (a) Samples B-1-1 and B-1-2 from Bagnotar open pit, (b) samples N1-1 and N-4-15 from Nathia Gali open pit.

declinations would be explained by local block rotations after the acquisition of ChRM. The oolitic ironstone bodies easily become a shear zone and fragmented into small blocks like a fault gauge, because they are thin-bedded and brittle compared with the surrounding limestones which are thick and massive. If these assembly of the beds are placed in the area of one of the most intensive deformation, the fragmented ironstone blocks should be repeatedly affected by shearing movements which provoke very local block rotations within the shear zone, though poor exposure prevented us to observe the block movement geologically.

On the other hand, the inclination of site-mean direction 

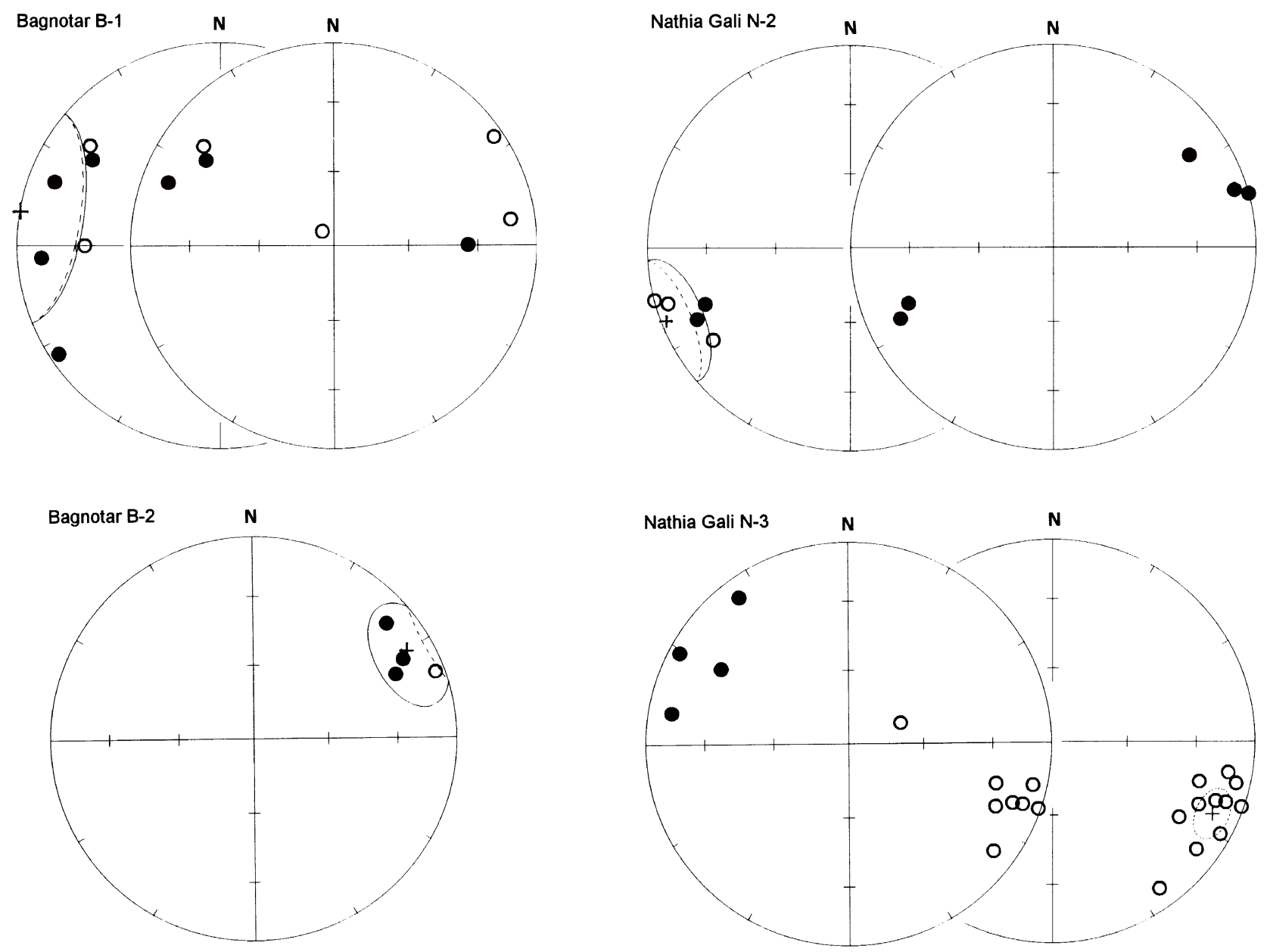

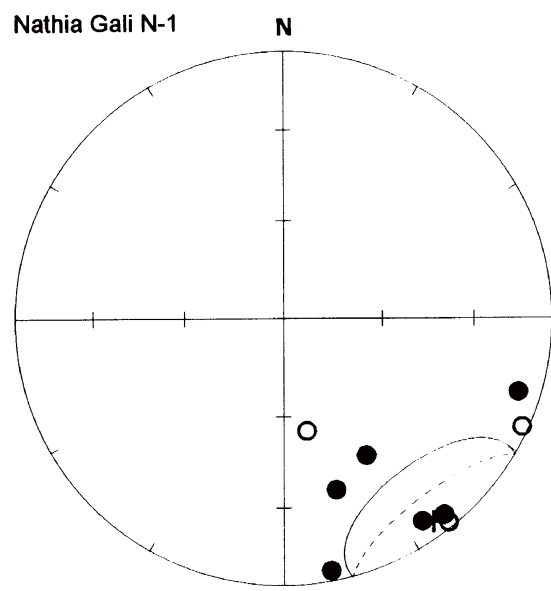

(a)

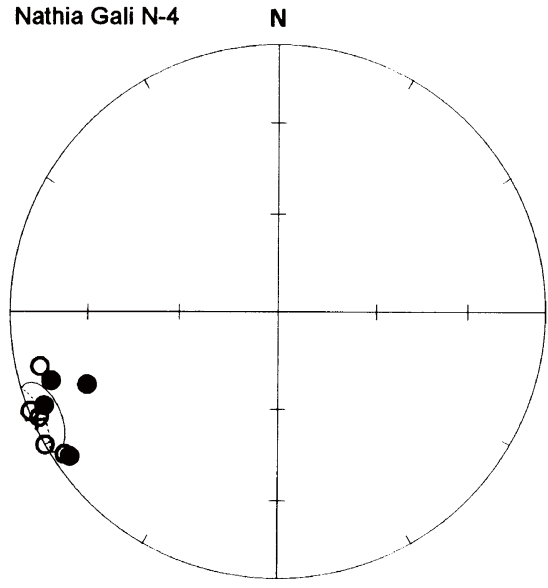

(b)

Fig. 7. Equal-area projections of ChRM directions after tilt correction. Solid symbols are projections onto horizontal plane, while open symbols are onto vertical plane.

can be always restored, if the bedding plane is well observed. As the bedding plane in the oolitic ironstone beds is clearly defined, the inclination of the oolitic ironstones would be determined by the tilt correction, if the ChRM is acquired when the strata was horizontal. The reversal test and the consistency in the site-mean inclination along with some rock magnetic evidences imply the ChRM was acquired before the tilting of strata. The shallow inclination due to the compaction of the beds can be ruled out, since the texture of ooids little show a deformation by the compaction.

The mean inclination is usually different from the average of inclination, but the bias is negligible with shallow data. (Enkin and Watson, 1996). As the inclination of oolitic ironstones is always shallow (Table 1), the mean inclination will be given by the average inclination (arithmetic mean of inclinations), $2^{\circ} \pm 6^{\circ}$, which correspond to a paleolatitude of $1^{\circ} \mathrm{N} \pm 3^{\circ}$. 


\section{Discussion}

\subsection{Origin of the ChRM}

The ChRM was acquired by fine-grained hematite which is mostly distributed in the darker rings of the ooids. Petrographic observations of the oolitic texture suggest that the remanence was acquired after consolidation of the ooids. Redeposition or internal deformation of ooids is highly unlikely after the acquisition of the ChRM component. Hematite $\left(\mathrm{Fe}_{2} \mathrm{O}_{3}\right)$ was probably formed by secondary diagenetic processes such as conversion of Fe-rich materials which were initially contained in unconsolidated ooids. It is generally believed that hematite in sedimentary rocks is mostly formed diagenetically from a hydrated ferric oxide precursor, e.g. an amorphous $\mathrm{FeO}-\mathrm{OH}$ or goethite, by an aging process that involves dehydration (Tucker, 1991), as follows:

$$
2 \mathrm{FeO}-\mathrm{OH} \rightarrow \mathrm{Fe}_{2} \mathrm{O}_{3}+\mathrm{H}_{2} \mathrm{O}
$$

The ChRM is a secondary CRM, which is carried by finegrained hematite that crystallized during diagenesis, after development of the oolitic texture.

\subsection{Paleolatitude}

The shallow inclination of the average ChRM suggests that the crystallization of fine-grained hematite and its acquisition of CRM occurred at low equatorial latitudes. The estimated paleolatitude of $1^{\circ} \mathrm{N} \pm 3^{\circ}$ is consistent with the paleoposition of the Indian subcontinent from late Cretaceous to Paleogene time as reconstructed by Klootwijk et al. (1992). According to their model of paleolatitudinal change of the Indian subcontinent, the timing of ChRM acquisition is estimated at around 60-65 Ma (early Paleocene).

Distribution of late Cretaceous-Paleocene oolitic ironstones has been reported along the continental margin of the Indian subcontinent (Sakai, 1983; Van Houten and Arthur, 1989; Van Houten, 1992; Garzanti, 1993). Paleomagnetic data from "hematite oolite" beds in the late Cretaceous/early Paleocene (K-T boundary) Amile Formation, Nepalese Lesser Himalaya (Sakai, 1983) also indicate low paleolatitudes $\left(7.4^{\circ} \mathrm{N}\right.$; Gautam, 1994), which agrees well with the present result.

\subsection{Paleoenvironment}

Initial Fe-rich material, probably amorphous hydroxides or goethite, was likely to have been produced by intense chemical weathering, lateritization, in a humid tropical climate in an equatorial region from the Cretaceous to the KT boundary (Figs. 8 and 9(A)). Deposition of this material along the continental margin is favored during marine transgressions and periods of reduced clastic sediment influx (Fig. 9(B)).

Siderite $\left(\mathrm{FeCO}_{3}\right)$, which has been identified in modern oolitic ironstone samples, precipitates at negative Eh, i.e., under reducing conditions, with high carbonate activity $\left(P_{\mathrm{CO}_{2}}\right)$ and low sulfide activity $\left(P_{\mathrm{S}^{2-}}\right)$ in sediment pore-waters (Krauskopf, 1967; Harder, 1989; Tucker, 1991). Low sulfide activity is rarely attained in marine sediments because of abundant dissolved sulfate. The sediments, which make up the initial form of the iron oolite, therefore, probably accumulated under non-marine or brackish conditions. The

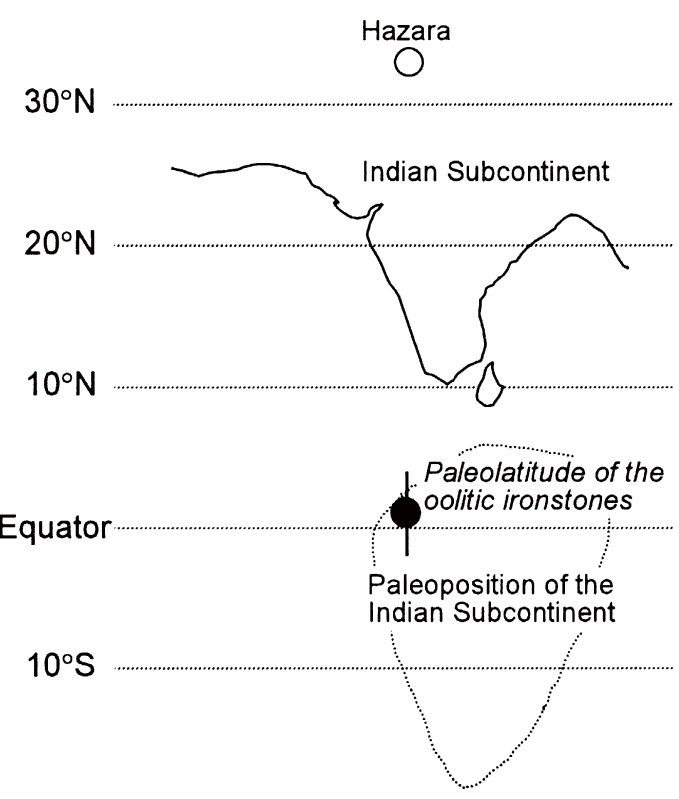

Fig. 8. Inferred paleogeographic position of the Hazara area (solid circle with error bar) and Indian Subcontinent (dotted line) at early Paleocene time. Open circle depicts present latitude of the Hazara area and solid line gives present coast line.

anoxic conditions that accommodate siderite precipitation may have also developed through bacterial decomposition of organic matter (Fig. 9(B)).

After formation and consolidation of the initial ooids, the material was converted to hematite-chamosite ooids during diagenesis, and acquired a CRM in early Paleocene time. The formation process of chamosite $\left((\mathrm{Mg}, \mathrm{Fe})_{3} \mathrm{Fe}_{3}\left(\mathrm{Si}_{3} \mathrm{Al}\right)\right.$ $\left.\mathrm{O}_{10}(\mathrm{OH})_{8}\right)$ is poorly understood, but it is assumed to precipitate in environments that fluctuate from oxic to anoxic conditions without sulfide activity (Kimberley, 1979; Tucker, 1991). The paleoenvironment must have changed from strongly reducing conditions to relatively oxidizing conditions because hematite is stable under moderate to strong oxidizing conditions (Krauskopf, 1967; Tucker, 1991). This environmental change implies dewatering of the strata accompanying the discharge of anoxic water (Fig. 9(C)), which may be related to upheaval of the terrane or to a low stand of sea-level at the early stages of initial collision between India and Asia. The environmental change from reducing to oxidizing conditions, the crystallization of finegrained hematite, and the acquisition of the CRM must have proceeded over relatively long time intervals, because the ChRM recorded geomagnetic polarity reversals.

\section{Conclusions}

(1) The Langrial iron ore in Bagnotar and Nathia Gali open pit mines, Hazara area, Northern Pakistan is a chamositehematite type oolitic ironstone. The magnetic properties of the oolitic ironstone are mostly derived from fine-grained hematite within ooids.

(2) The paleoenvironment during deposition of initial Fe-rich sediments (amorphous hydroxides or goethite) represents an anoxic, organic rich, reducing situation in a non-marine or brackish environment. During early diagenesis, after development of the oolitic texture, the 
(C) early Paleocene (60-65 Ma)

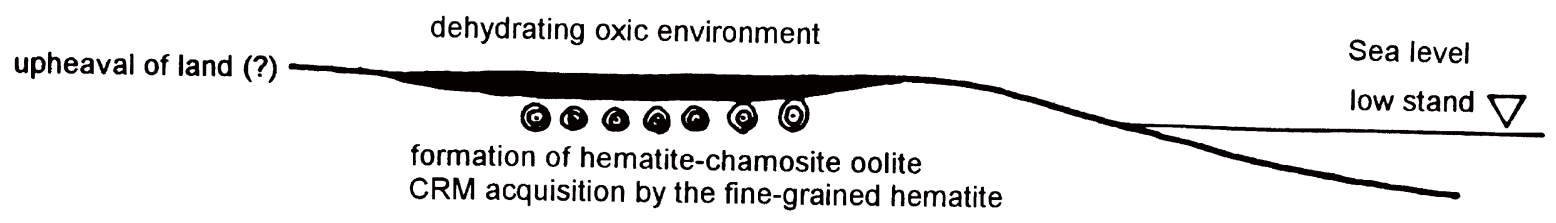

$\Uparrow$

(B) late Cretaceous (?) to K-T boundary (before $65 \mathrm{Ma}$ ) consolidation of oolite

$\Uparrow$

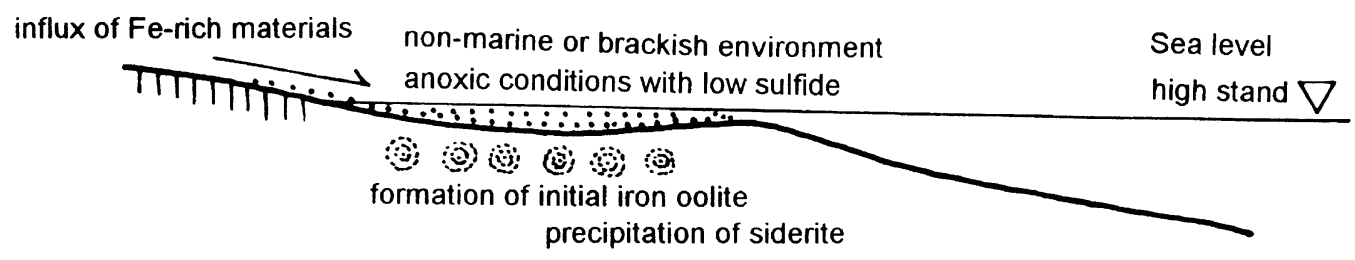

(A) late Cretaceous (?) to K-T boundary (before $65 \mathrm{Ma}$ )

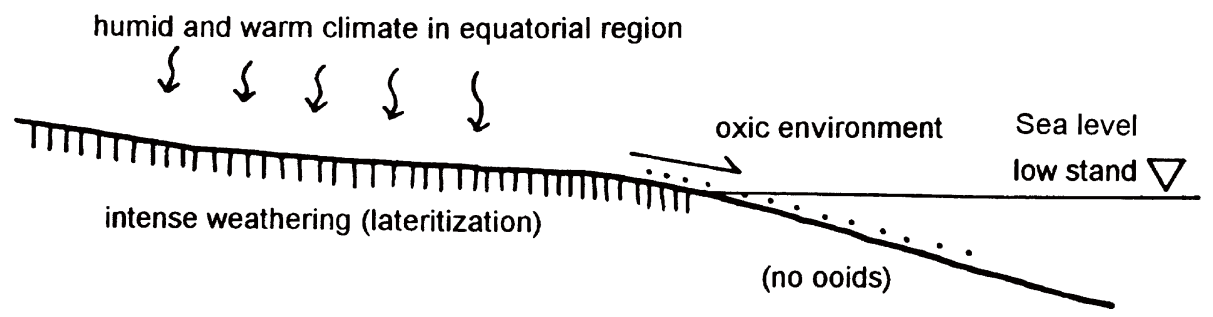

Fig. 9. Inferred paleoenvironmental conditions during formation of the oolitic ironstone beds, Hazara Area, Pakistan.

paleoenvironment changed and oxidizing, dehydrating conditions prevailed. The ChRM is a CRM that is carried by fine-grained hematite which crystallized under oxidizing conditions in an equatorial region (latitude $1^{\circ} \mathrm{N} \pm 3^{\circ}$ ) in early Paleocene time (60-65 Ma).

(3) Local block rotations of the oolitic ironstone beds may have repeatedly taken place after acquisition of the CRM, which were probably caused by intense structural disturbances related to India-Asia collision since early Tertiary time.

Acknowledgments. We thank Tahir Karim, Sakiyuki Mononobe, and Mohammad Ali for their help with field work. We also thank Afshan Aslam for her help with XRD analysis, and Iftikhar Mustafa Khadim and Huma Akram for their assistance concerning laboratory work. Our special thanks to S. Hasan Gauhar, Muhammad Sakhawat, Junkichi Yajima, Yoshiya Ikeda, and Teruo Shirahase. Critical reviews by Andrew Roberts, Minoru Funaki, and Hidetoshi Shibuya allowed considerable improvements to be made to the manuscript and figures. This collaborative research programme was supported by the Geoscience Laboratory Project, a technical cooperation project between GSP (Geological Survey of Pakistan) and JICA (Japan International Cooperation Agency).

\section{References}

Ahmad, Z., Directory of mineral deposits of Pakistan, Rec. Geol. Surv. Pakistan, 15, 1-220, 1969.
Blatt, H., G. Middleton, and R. Murray, Origin of Sedimentary Rocks, 2nd ed., 782 pp., Prentice-Hall, Inc., Englewood Cliffs, 1980.

Butt, A. A., An overview of the Hazara arc stratigraphy, northern Pakistan, Geol. Bull. Punjab Univ., 24, 1-11, 1989.

Carmichael, R. S., Practical Handbook of Physical Properties of Rocks and Minerals, 741 pp., CRC Press, Boca Raton, 1989.

Enkin, R. J. and G. S. Watson, Stastical analysis of paleomagnetic inclination data, Geophys. J. Int., 126, 495-504, 1996.

Fatmi, A. N., Lithostratigraphic units of the Kohat-Potwar Province, Indus Basin, Pakistan, Mem. Geol. Surv. Pakistan, 10, 1-80, 1974.

Garzanti, E., Himalayan ironstones, "superplumes", and the breakup of Gondwana, Geology, 21, 105-108, 1993.

Gautam, P., Paleomagnetism of the redbeds of the Tansen Group in the Lesser Himalaya Nepal: Its stratigraphic and tectonic implications, in Geology in South Asia-I, Proc. 1st South Asia Geol. Congr., edited by R. Ahmed and A. M. Sheikh, 423 pp., Hydrocarbon Development Institute of Pakistan, Islamabad, 1994.

Gilbert, J. M. and C. F. Park, Jr., The Geology of Ore Deposits, 985 pp., W. H. Freeman, New York, 1986.

Hallam, A. and J. B. Maynard, The iron ores and associated sediments of the Chichali formation (Oxfordian to Valanginian) of the Trans-Indus Salt Range, Pakistan, J. Geol. Soc., London, 144, 107-114, 1987.

Harder, H., Mineral genesis in ironstones: A model based upon laboratory experiments and petrographic observation, Spec. Publ. Geol. Soc. Lond., 46, 9-18, 1989.

Ibrahim Shah, S. M., Stratigraphy of Pakistan, Mem. Geol. Surv. Pakistan, 12, 1-138, 1977.

Kazmi, A. H. and R. A. Rana, Tectonic Map of Pakistan, Geological Survey of Pakistan, Quetta, 1982.

Khan, S. N. and W. Ahmad, Geology of Langrial iron ore, Hazara District, Geol. Surv. Pakistan Pre-Publ. Issue, 25, 1-15, 1966. 
Kimberley, M. M., Origin of oolitic iron formation, J. Sediment. Petrol., 49, 111-132, 1979.

Kimberley, M. M., Debate about ironstone: Has solute supply been surficial weathering, hydrothermal convection, or exhalation of deep fluids?, Terra Nova, 6, 116-132, 1994.

Klootwijk, C. T., J. S. Gee, J. W. Peirce, G. M. Smith, and P. L. McFadden, An early India-Asia contact: Paleomagnetic constraints from Ninetyeast Ridge, ODP leg 121, Geology, 20, 395-398, 1992.

Krauskopf, K. B., Introduction to Geochemistry, 721 pp., McGraw-Hill, New York, 1967.

Lowrie, W. and F. Heller, Magnetic properties of marine limestones, Rev. Geophys. Space Phys., 20, 171-192, 1982.

Maynard, J. B., Geochemistry of Sedimentary Ore Deposits, 305 pp., Springer-Verlag, New York, 1983.

McFadden, P. L. and M. W. McElhinny, Classification of the reversal test in paleomagnetism, Geophys. J. Int., 103, 725-729, 1990.

Sakai, H., Geology of the Tansen Group of the Lesser Himalaya in Nepal, Mem. Fac. Sci. Kyushu Univ., D25, 27-74, 1983.

Taylor, K. G., Non-marine oolitic ironstones in the Lower Cretaceous
Wealden sediments of southeast England, Geol. Mag., 129, 349-358, 1992

Tucker, M. E., Sedimentary Petrology, 2nd ed., 260 pp., Blackwell Sci. Publ., London, 1991.

Van Houten, F. B., Review of Cenozoic ooidal ironstone, Sedi. Geol., 78, 101-110, 1992.

Van Houten, F. B. and M. A. Arthur, Temporal patterns among Phanerozoic oolitic ironstones and oceanic anoxia, Spec. Publ. Geol. Soc. Lond., 46, 33-49, 1989

Young, T. P. and W. E. G. Taylor (eds.), Phanerozoic Ironstones, Spec. Publ. Geol. Soc. Lond., 46, 1-251, 1989.

Zijderveld, J. D. A., A.C. demagnetization of rocks: Analysis of results, in Methods in Paleomagnetism, edited by D. W. Collinson, K. M. Creer, and S. K. Runcorn, Elsevier, Amsterdam, 1967.

M. Yoshida (e-mail: myoshida@mtci.or.jp), I. H. Khan (e-mail: ibrar@geolab.sdnpk.undp.org), and M. N. Ahmad (e-mail: naseel@cosmos.sci.hokudai-ac.jp) 